\title{
The impact of drainage towards roads in maintenance cost
}

\author{
Erna Ismiyani ${ }^{1, *}$, Dewi Handayani ${ }^{2}$, and RR. Rintis Hadiani ${ }^{2}$ \\ ${ }^{1}$ Student of Civil Engineering Master Program, Sebelas Maret University, Surakarta, Indonesia \\ ${ }^{2}$ Lecturer of Civil Engineering Master Program, Sebelas Maret University, Surakarta, Indonesia
}

\begin{abstract}
An ideal road infrastructure has a low cost for maintenance and better performance of the roads and drainage systems. The disintegrated maintenance system between the roads and drainage is the major cause of an increasing road maintenance cost. Therefore, this research aimed to investigate the impact of drainage towards roads in maintenance cost. This paper is located in Surakarta which was divided into eight catchment areas. The main variables of this paper are cost maintenance of drainage and roads, which were analyzed using regression. These variable data were obtained from the total cost per year allocated by Surakarta City Government on the urban drainage and local road maintenance budget from 2013 to 2017. The results showed that low drainage maintenance cost tended to result in high road maintenance cost.
\end{abstract}

\section{Introduction}

The main cause of road failure is construction materials, traffic load, climate and water [1, 2]. Drainage becomes a problem when a ditch is not functioning properly to direct and carry the run off away due to improper physical condition, capacity and maintenance [3]. The effect of water puddles on the road is a weakening of the soil load carrying capacity followed by the acceleration of the pavement cracking process [4].

The efforts to maintain road failure are not only focused on improving the pavement (overlay and road reconstruction) but also in planning the construction of subsurface drainage infrastructure to be able to release water that can weaken the pavement of the road from within [5]. The integration of drainage and the road system is done by concerning the factors that influence urban drainage systems, which are: a) rainfall intensity, b) catchment area, c) urban growth such as physical growth of the city, balance of development within city and between city and social factor, economy and culture, d) terrain and environmental factors such as topography and soil stability [6,7]. However, in the implementation, road and drainage system management has not been integrated.

The ideal road infrastructure provision requires a low maintenance cost, and good roads and drainage performance. Drainage plays a role in preventing the types of road construction failures caused by puddles on the road surface or water infiltration on the pavement $[8,9]$.

\footnotetext{
* Corresponding author: e.ismiyani@gmail.com
} 
Drainage normalization and collapsed drainage walls are one of the activities in routine road maintenance [10]. Effective execution on roads and drainage maintenance can reduce the total road maintenance costs to be spent [11].

From previous studies, it was showed that there is a strong correlation between drainage and road conditions and this also indicates a correlation to the maintenance costs of both infrastructures. This paper examines what the impact of drainage towards the road in terms of maintenance costs is, with a hypothesis that if the cost of drainage maintenance increases, so the cost of road maintenance decreases.

\section{Theory and methodology}

\subsection{Theory}

\subsubsection{Factors affecting the service life of drainage and roads}

Aside from traffic load overcapacity, the effect of water on road pavement has a major impact. Run off has to be drained quickly from the pavement in order to not to disrupt the carrying capacity of pavement material construction. Road networks should be integrated with the drainage system to reach the service life of road [12]. During and after floods, it shows that there are significant impacts on the roads' failure. Based on the field survey and observation, these floods are merely caused by a clogged drain or mud sedimentation, even though the design capacity can still cover demands [13].

In managing the urban drainage system, it is important to concern the following: a) water resources management plan, b) urban land use planning (RUTRK), c) urban/regional typology, d) water conservation, e) environmental, social, economic, and local wisdom. [14] Unintegrated management of the road and drainage infrastructure is characterized by deterioration in the quality of municipal infrastructure and other utilities, odor and environmental pollution, urban land degradation, and disease-induced organism development. [5] Geographic, geological and soil conditions have an influence on the drainage problems. Flat slopes of the land, saturated soil, and the high groundwater level increase the possibility of water puddles [12]

\subsubsection{Drainage and road maintenance cost}

Road maintenance includes routine maintenance activities, periodic maintenance, road rehabilitation and road reconstruction. On the road maintenance routine, the aim is to maintain the function and to minimize structure or road surface failure. Continuously cleaning the ditch from the mud, piles of dirt, and garbage is one of the routine road maintenance activities. In addition to this, there is a maintenance of complementary road buildings that are carried out throughout the year, such as general cleaning, disposal of wild plants and garbage, cleaning and drainage, etc. Meanwhile, periodic maintenance is done by maintaining the function of supplementary road building to improve drainage performance [2].

Pavement condition and problem definition could be determined by evaluating the following eight major categories of the existing pavement which are: (1) structural adequacy (load related), (2) functional adequacy (user related), (3) subsurface drainage adequacy, (4) material durability, (5) shoulder condition, (6) extent of maintenance activities performed in the past [15].

The basic principle of urban drainage maintenance is done to prevent damage and/or prevent the decrease of drainage infrastructure function. Maintenance activities include 
routine maintenance; periodic maintenance; rehabilitation; and special maintenance. Rainfall in an area needs to be accommodated, impregnated, and followed by means of water reservoirs, infiltration facilities, and drainage ditch/channels that then flows to a larger water [14].

\subsection{Methodology}

\subsection{Location}

The road studied is a municipal road with a local road function and flexible pavement that is stated in the Decree of the Mayor of Surakarta Number: 762/52.1/1/2016 on Stipulation of the Status of the Road as the Surakarta Municipal Road. The drainage examined is an infrastructure system authorized by the Surakarta Municipal Government covering environmental, tertiary and secondary drainage systems. Eight catchment areas (DTA) in the urban's drainage system were Kalianyar, Gajah Putih, Pepe Hulu, Tanggul, Jenes, Wingko, Pepe Hilir and Bengawan Solo. The characteristics of each catchment area can be seen in Figure 1.

A local road is a public road that serves local transport with characteristics of shortdistance travel, lower average speed, and a limited number of entrances [6]. The municipal road means a secondary road network system that connects the inter-city service centre, connecting the centre of services with the plot connecting between the arms and connecting between settlement centres within the city. Authority of road management is under the Surakarta Municipal Government. The drainage examined was the drainage infrastructure system which was the authority of the Government covering environmental drainage, tertiary, and secondary. 


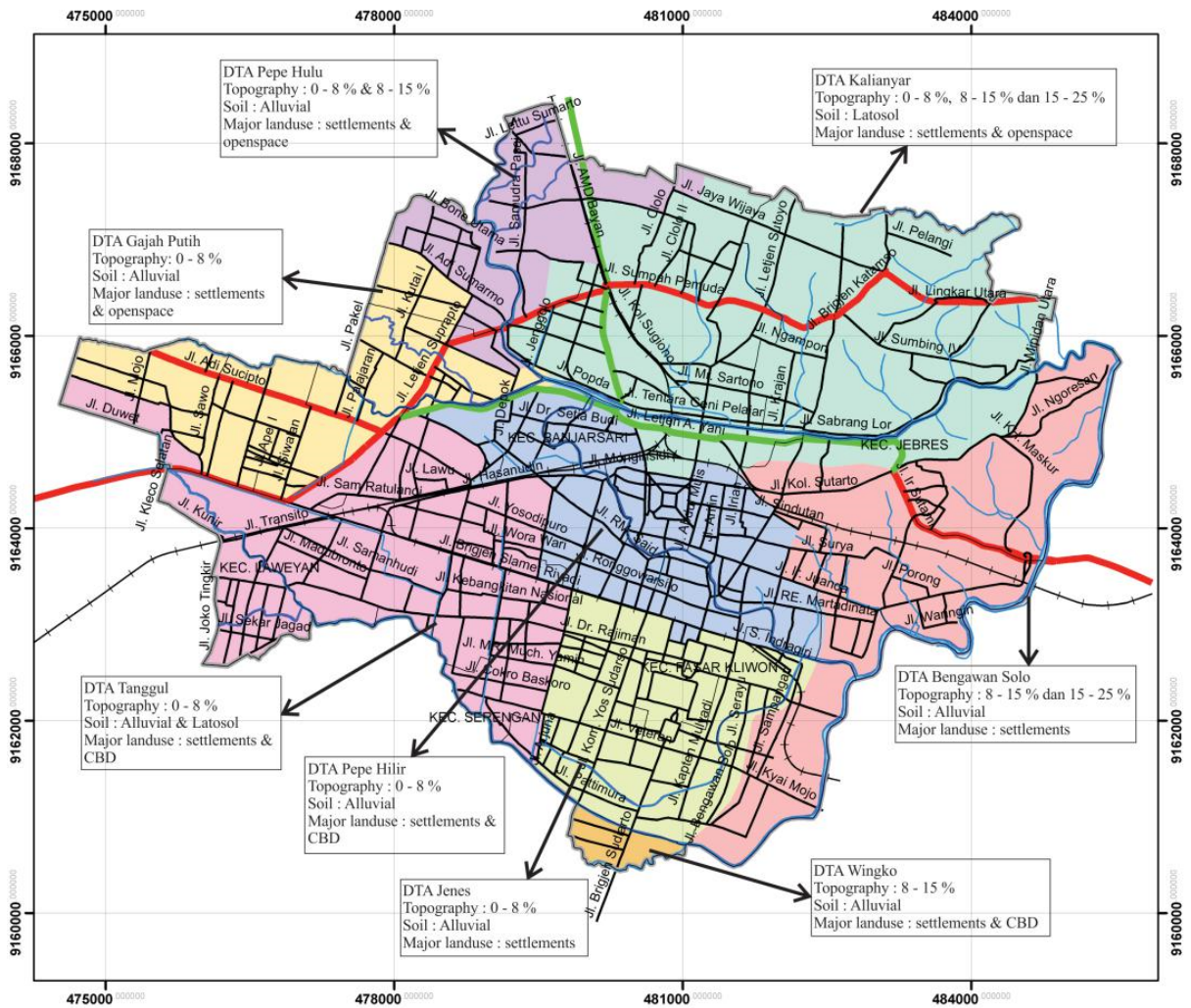

Fig. 1. Map of roads and eight catchment areas in Surakarta City.

\subsubsection{Data and analysis}

The data collected was that of the drainage and road maintenance cost in Surakarta with the observation period of data budget from 2014 until 2017 and catchment area characteristic in the form of topography, soil type, and land use.

Data analysis used regression tools to study the relationship between variable $\mathrm{x}$ that was the maintenance cost of drainage and variable y that was road maintenance cost, both were in units IDR $/ \mathrm{Km}^{2}$. To equalize the data unit of road and drainage maintenance cost to IDR / $\mathrm{Km}^{2}$, it required the data which consists of name, width, length, and location of the road in Surakarta city with local road type and municipal road status as well as data of the area and location of catchment area in Surakarta City.

\section{Discussion}

\subsection{Catchment area characteristic}

In terms of topography, the catchments area of Gajah Putih, Jenes, Pepe Hilir, and Tanggul have the same slope of $0-8 \%$, while Pepe Hulu and Bengawan Solo varies slightly with a slope of $0-8 \%$ and Kalianyar has the highest slope, from $0-8 \%, 8-5 \%$, and $15-25 \%$. Areas with high slope gradients will be easier in regulating the flow of surface water, in contrast to areas with flat slopes. Areas with a flat slope require planning and regulation of water flow more thoroughly as it is more at risk of puddles. 
Table 1. Catchment area characteristic.

\begin{tabular}{|c|c|c|c|c|c|c|c|c|}
\hline \multirow{2}{*}{$\begin{array}{c}\text { Characteristic } \\
\text { of DTA }\end{array}$} & \multicolumn{8}{|c|}{ Catchment Area/DTA Name } \\
\hline & $\begin{array}{l}\text { Gajah } \\
\text { Putih }\end{array}$ & $\begin{array}{l}\text { Pepe } \\
\text { Hulu }\end{array}$ & $\begin{array}{c}\text { Kali } \\
\text { anyar }\end{array}$ & $\begin{array}{c}\text { Benga- } \\
\text { wan Solo }\end{array}$ & Wingko & Jenes & $\begin{array}{l}\text { Pepe } \\
\text { Hilir }\end{array}$ & $\begin{array}{l}\text { Tang- } \\
\text { gul }\end{array}$ \\
\hline $\begin{array}{l}\text { Topography } \\
\text { (\%) }\end{array}$ & $0-8$ & $\begin{array}{c}0-8 \\
8-15\end{array}$ & $\begin{array}{c}0-8 \\
8-15 \\
15-25 \\
\end{array}$ & $\begin{array}{c}8-15 \\
15-25\end{array}$ & $8-15$ & $0-8$ & $0-8$ & $0-8$ \\
\hline Soil & Alluvial & Alluvial & Latosol & Alluvial & Alluvial & Alluvial & Alluvial & Alluvial \\
\hline $\begin{array}{l}\text { Major Land } \\
\text { use }\end{array}$ & $\begin{array}{c}\text { - Settle } \\
\text { ment } \\
\text { - open } \\
\text { space }\end{array}$ & $\begin{array}{c}\text { - Settle } \\
\text { ment } \\
\text { - open } \\
\text { space }\end{array}$ & $\begin{array}{r}- \text { Settle } \\
\text { ment } \\
- \text { open } \\
\text { space }\end{array}$ & settlement & $\begin{array}{c}\text { Settle- } \\
\text { ment }\end{array}$ & $\begin{array}{r}\text { - Settle } \\
- \text { ment } \\
- \text { CBD }\end{array}$ & $\begin{array}{r}- \text { Settle } \\
- \text { ment } \\
- \text { CBD }\end{array}$ & $\begin{array}{c}- \text { Settle } \\
\text {-ment } \\
\text { CBD }\end{array}$ \\
\hline
\end{tabular}

In terms of soil type, only one DTA has a latosol soil type while the other one has alluvial soil. Latosol soil properties have a good enough water capacity, an infiltration with speed that is rather quick and it is slow and resistant to erosion. The soil properties of alluvial are that it is erosion-sensitive and it is usually located on the banks of large rivers and swamps so as to easily reach the water saturation point. Catchment Area located in South Surakarta namely Tanggul, Jenes, Pepe Hilir, Tanggul and Bengawan Solo is a former swamp.

Based on the main land use, three catchment areas, namely Gajah Putih, Pepe Hulu, and Kali Anyar still have open space that can help the function of water absorption on the ground. Bengawan Solo and Wingko are predominantly settlements while Jenes, Pepe Hilir, and Tanggul are already a mix of settlements and Central Business District (CBD) so that the activities and infrastructure facilities in this region become more various, thus affecting the existing drainage system.

Based on those three reviews, catchment areas that have potentially more complex drainage issues are Catchment Areas with flat slope, swampy land type, and dense land use, with no adequate open space.

\subsection{Correlation analysis between drainage and roads maintenance cost}

As stated in the research method, analysis has been done by a regression analysis technique to find the relationship between drainage and road maintenance cost. The results of the analysis on the eight catchment area (DTA) are shown in Fig. 2. 


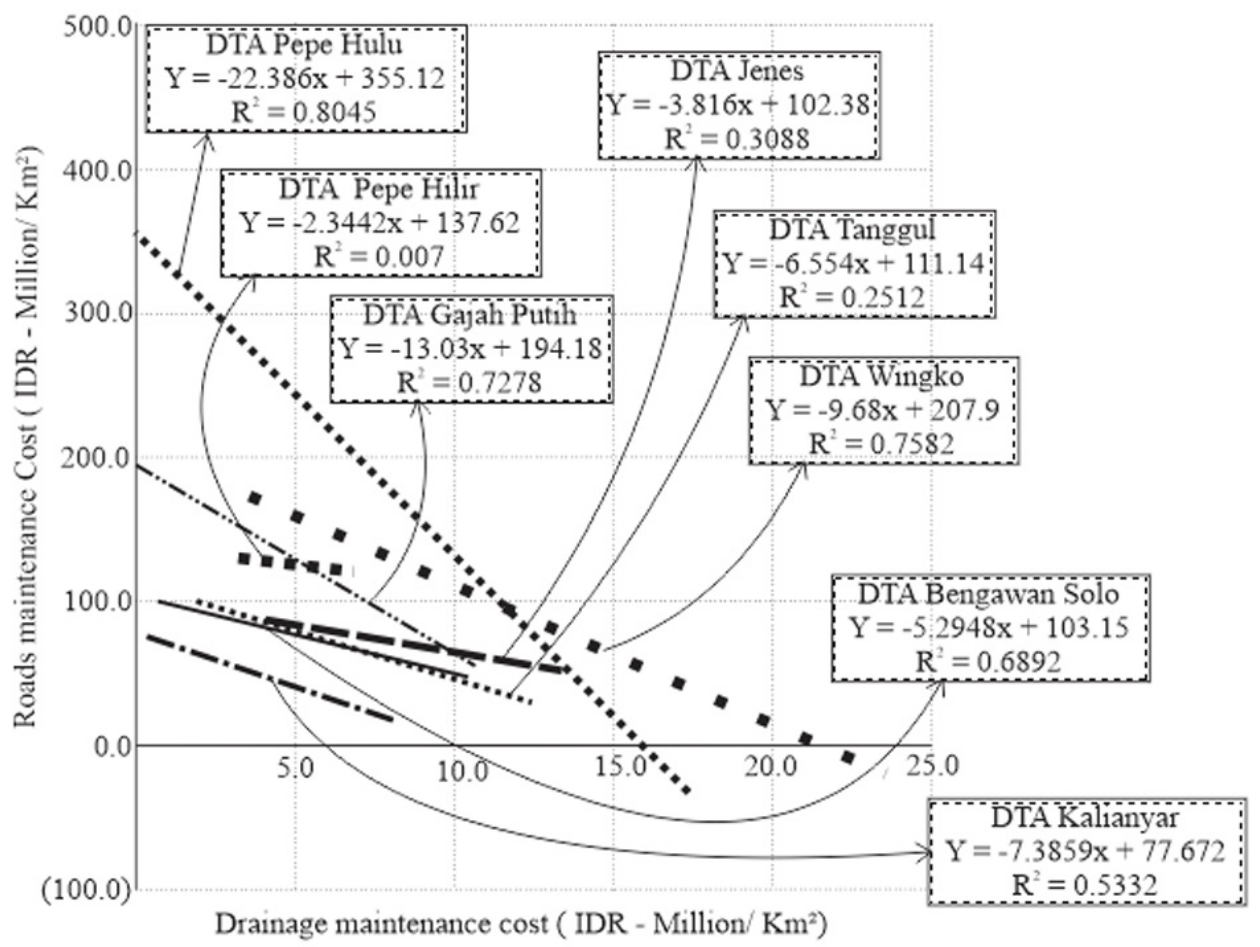

Fig 2. Linear regression charts of drainage and roads maintenance cost on 8 catchment areas in Surakarta City.

The regression results show that five catchment areas have a high determinant coefficient $\left(\mathrm{R}^{2}>0,5\right)$. The determinant coefficient is a value that shows how strong the independent variable influences the dependent variable, ranging from 0 to 1 . Those catchment areas with high values of $\mathrm{R}^{2}$ are Pepe Hulu, Gajah Putih, Wingko, Bengawan Solo and Kalianyar. The models of the above chart prove the strong correlation that the addition of drainage maintenance cost will lower the road maintenance cost. Bazlamit's study, 2017 concluded that proper maintenance of road and drainage systems can reduce the total road handling costs [8]. Judging from the catchment area's characteristics, these five have similarities which are diverse slopes, contoured, not flat, alluvial soil types that are not ex-swamp, dense land use, and the existence of open space as a water absorption area.

In contrast to the three, the catchment area (Tanggul, Jenes, and Pepe Hilir) shows a weak relationship between the drainage and road maintenance costs. Judging from the characteristics of the Catchment Areas, there are factors that affect the complexity of the drainage system. The three catchment areas have flat slopes, swampland soil type, and dense land use without any open space. These factors resulted in the drainage maintenance cost allocation not being significant to the road maintenance cost because the drainage system problem has not been resolved thoroughly with the existing cost allocation. as Additionally, research was done by Sulistiyatno, 2012 which states that there are natural factors that affect the drainage system [11].

\section{Conclusions and recommendations}

From the analysis, it can be concluded that in the catchment area locations with open space, no $\mathrm{CBD}$ and various high slopes, there is a strong correlation between drainage and road 
maintenance costs. The bigger the drainage maintenance cost allocations is the required road maintenance cost will decrease.

The recommendations for refining the research are the addition of variables related to catchment area characteristics, drainage performance, and road performance.

\section{References}

1. Sosrodarsono, Hidrologi untuk Pengairan, (Penerbit Pradnya Paramita, Jakarta, 1976)

2. J.U.D. Hatmoko, B.H. Setiadji, M.A. Wibowo. Evaluasi pengaruh banjir, beban berlebih dan mutu konstruksi pada kondisi jalan. Proceeding of FSTPT ch.9. (2016)

3. Singh, et all. Drainage on Roads, IJPCE Vol -1 (2014)

4. A. Ababa, Road \& urban storm water drainage network integration. JETR Vol. 3(7). (2011)

5. Republik Indonesia, Kementrian PU. Kajian Pengaruh Drainase dan Muka air Tanah terhadap Perkerasan Jalan. (Puslitbang jalan dan jembatan, Bandung, 2011)

6. Republik Indonesia. Peraturan Pemerintah No. 34 tahun 2006 tentang Jalan. Lembaran Negara Republik Indonesia (No 86. Menhumkam, Jakarta, 2006)

7. Republik Indonesia, Peraturan Menteri Pekerjaan Umum No: 13/PRT/M/2011 tentang Tata Cara Penilikan Jalan. Berita Negara Republik Indonesia (No. 612. Menhumham, Jakarta, 2011)

8. S.M. Bazlamit, H.S Ahmad, Turki I. Al Suleiman. Pavement Maintenance Applications using GIS. Procediaa Engineering 182 (2017)

9. Munggarani. Faktor penyebab kerusakan perkerasan jalan lentur terhadap biaya penanganan. Jurnal Infrastruktur Vol. 2 No. 01 (2017)

10. Nurhidayah. Studi genangan air terhadap Kerusakan Jalan di Kota Gorontalo. Simposium XII FSTPT (2009)

11. A. Sulistiyatno, M. D. Fajri, I.B. Moctar. Pengaruh genangan air terhadap kerusakan jalan aspal dan perencanaan subdrain. Jurnal Teknik POMITS Vol. 1 No. 1 (2012)

12. S.P.R. Wardani, Suripin, Soebroto, Muhrozi, B.H Setiadji. Sistem drainase pada jalan pantura: permasalahan dan alternatif solusi. Seminar nasional teknik jalan ke-3. (2015)

13. J.U.D. Hatmoko, B.H. Setiadji, M.A. Wibowo. Evaluasi pengaruh banjir, beban berlebih dan mutu konstruksi pada kondisi jalan. Proceeding of FSTPT ch.9. (2016)

14. Republik Indonesia, Peraturan Menteri Pekerjaan Umum No: 12/PRT/M/2014 tentang Penyelenggaraan Sistem Drainase Perkotaan. Berita Negara Republik Indonesia (No. 1451. Menhumham, Jakarta, 2014)

15. AASHTO. Mechanistic-empirical pavement design guide, (American Association of State Highway and Transportation Officials, United States of America, 2008) 